\title{
Mapping the Physical Properties of Soils and the California Bearing Ratio (CBR) Value for Different Soil Types: A Case Study in the Bukit Kemuning and Pugung Tampak Areas
}

\author{
LUSMEILIA AFRIANI $^{1}$, NURSYIRWAN ${ }^{2}$, RYZAL PERDANA $^{3}$, RINA FEBRINA $^{4}$ \\ YAN JUANSYAH ${ }^{4}$ \\ ${ }^{1}$ Department of Civil Engineering, Faculty of Engineering, University of Lampung, INDONESIA \\ ${ }^{2}$ Department of Mathematics, Faculty of Mathematics and Natural Sciences, University of Lampung, \\ INDONESIA \\ ${ }^{3}$ Department of Educational Sciences, Faculty of Teacher Training and Education, University of \\ Lampung, INDONESIA \\ ${ }^{4}$ Department of Civil Engineering, Faculty of Engineering, Universitas Malahayati, INDONESIA
}

\begin{abstract}
It is widely accepted that soil is a mixture of mineral constituents that have accumulated over time. The physical characteristics of soil vary according to the mineral and organic matter content and the process of formation. The soil's unique characteristics have been the subject of research in the field of civil engineering, which has continued to evolve to the present day due to the land's requirement for civil engineering construction, such as road paving. As a result, the current study sought to determine the similarity of soil samples based on their physical properties and California Bearing Ratio (CBR) values, as well as the relationship between the soil's physical properties and CBR values. To our knowledge, there is hardly little research in the literature investigating the topic under our investigation. Furthermore, we also mapped the physical characteristics and CBR values of numerous distinct soil samples using a Geographical Information System (GIS). This study concentrated on the West Lampung Regency, specifically the area between Bukit Kemuning in Central Lampung and Liwa in West Lampung, along the lines of Bukit Kemuning, Liwa, and Krui, all the way to the Lampung - Bengkulu province border. The soil samples from the area were taken for two tests: the unsoaked CBR test and the soaked CBR test. The results of the tests show that a 31-kilometre distance does not result in a significant difference in soil properties, which are generally similar except in clay-rich areas. Furthermore, the results of the laboratory analysis show that the amount of water in the soil sample affects the Liquid Limit (LL), Plastic Limit (PL), Maximum Dry Density (MDD), and CBR values; the lower the plastic limit value, and thus the lower the CBR value, the less water in the soil. The implications of the current findings are also discussed.
\end{abstract}

Key-Words: - California Bearing Ratio, soil physical properties, soil types, construction, pavement

Received: April 30, 2021. Revised: November 11, 2021. Accepted: December 12, 2021. Published: January 9, 2022.

\section{Introduction}

It is publicly accepted that soil is a material composed of a variety of mineral constituents that have accumulated over time [1]-[3]. It is reported in the literature that almost no two soil types are identical in terms of physical and mechanical characteristics [4], despite the fact that they are extracted from adjacent areas. Thus, the uniqueness of this soil's nature necessitates additional research [5], [6]. Therefore, we aim to be able to map the state of soil qualities and serve as a model for other areas in theory, looking for methods to specific soil structures.

The reason for soil composition differences begins with the way the soil is formed and the material content of the soil. Thus, the soil material is referred to as organic material or organic matter. Additionally, soil materials can be classified as cohesive or non-cohesive, depending on the particle's tendency to stick together [7], [8]. The physical properties of soil include its structure, porosity, density, and fertility, all of which have a 
positive and significant effect on the elements contained within [9]-[11].

The soil's unique nature has been the subject of research [6] in the field of civil engineering, which has continued to develop to the present day because the land is required to support civil engineering construction, such as road paving. Physical characteristics of soil vary according to the amount of mineral and organic matter present and the formation process [12]. The spatial variability of soil physical properties is revealed at a large scale by capturing its variations using geostatistics from a few metres to kilometres based on variograms and variables [13]-[19].

In general, the pavement must be capable of bearing the weight of the vehicles that pass through it. The road surface can withstand the friction generated by the wheels, as well as the effects of rainwater [11]. If the pavement is not strong enough, the road will deteriorate and shear, both on the pavement and on the subgrade. As a result, the road will suffer damage, specifically in the form of small holes that will eventually become large holes, destroying the pavement completely. To deeply investigate this, a California Bearing Ratio (CBR) test is one of the subgrade mechanical strength tests. The CBR is a penetration test that is used to determine the mechanical strength of subgrades for new road construction. The California Department of Transportation developed CBR tools prior to World War II [20].

CBR testing is conducted in the laboratory and in the field using CBR test equipment. The CBR test is also referred to as a penetration test because it is used to determine the fundamental strength of roads, parking lots, and sidewalks. The results of this test are combined with empirical curves to determine the road's and component layers' thickness. This is the most frequently used method for designing flexible pavements [21], [22].

Furthermore, the strength of the subgrade is dependent on its moisture content. The higher the water content, the weaker the soil's CBR strength. There is extensive local experience with a specific soil type [23]. This does not mean that the subgrade should be compacted with low moisture content in order to achieve a high CBR value, as the moisture content of the soil will soften during compacting [24]. Following road construction, water will be able to seep into the subgrade, reducing the CBR strength until the moisture content reaches a constant value [25], [26]. The so-called "balanced water content" refers to this constant water content. The moisture content and dry bulk density limits can be determined using laboratory experiments, specifically compaction and CBR tests. The CBR experiment can be conducted in two ways: unsoaked or soaked [27], [28].

Therefore, in the Bukit Kemuning and Pugung Tampak areas, we sought to determine the similarity of soil samples based on the physical qualities of the soil and the CBR value, as well as the relationship between the physical properties of the soil and the CBR value. To our knowledge, there is hardly little research in the literature investigating the topic under our investigation. We also mapped the physical characteristics and CBR values of numerous distinct soil samples using a Geographical Information System (GIS) [29]-[31]. The CBR value and the physical parameters of the soil were utilised to identify the characteristics of a soil sample. A map was created using the findings of laboratory test data processing and GIS applications. Using spatial databases linked to geographic features in GIS, it is possible to identify places that can be utilised as road bodies immediately or that need to be treated before being used [32], [33].

\section{Materials and Methods}

This study concentrated on the West Lampung Regency, specifically the area between Bukit Kemuning in Central Lampung and Liwa in West Lampung, along the lines of Bukit Kemuning, Liwa, and Krui, all the way to the Lampung - Bengkulu province border (see Figure 1). Because this area is prone to minor earthquakes and is hilly, it receives a lot of rain. The soil sample taken served as a reference for the road repair plan because road improvement work was going on in the area at the time of the investigation.

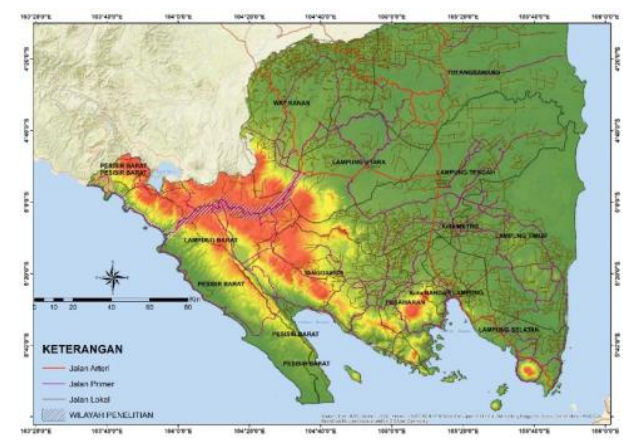

Fig. 1: Research Site 
The soil samples from the area were taken for two tests: the unsoaked CBR test and the soaked CBR test. Soaked CBR values were obtained by immersing soil samples in water for four days.

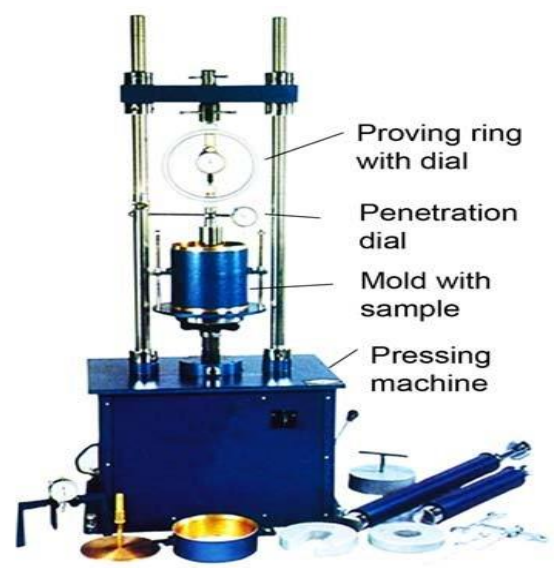

Fig. 2: CBR Test Equipment Source: [34]

The basic premise of CBR testing is to propel a plunger cylinder with a diameter of $50 \mathrm{~mm}$ into the soil or pavement component material to be tested at a velocity of $1.25 \mathrm{~mm}$ per minute. The weights necessary to cause plunger penetration of $2.5 \mathrm{~mm}$ and $5.0 \mathrm{~mm}$ in the soil/material under test are recorded [35]. The CBR test is primarily used to determine the modulus and shear strength of subgrades. The ductile modulus of the subgrade, which has been connected with the CBR in the American Association of State Highway and Transportation Officials (AASHTO) design code, determines the pavement layer thickness [36].

To obtain particles smaller than No. 4 , the soil was drained and sieved. The filter's output could be used to display the physical characteristics of the soil, such as its plastic properties at various moisture levels. The compaction value was determined in the first experiment. The optimum moisture content and maximum dry density were obtained using a standard proctor.

Each test parameter was run three times, with the averaged result. Soil samples were taken in two ways: undisturbed and disturbed. As needed, the sample quantity was used. The soaked CBR test was required to anticipate when rainwater puddled and soaked into the soil, causing the soil's strength to deteriorate. The lowest score was used as the benchmark by the planner. The results of the soil physical properties experiment, such as moisture content, density, volume weight, plasticity index, compaction, and CBR, were presented in the form of figures and graphs depicting the relationship between the two.
In addition, Gabriel introduced a bi-plot analysis, which was used to map soil characteristics, in 1971. Essentially, by superimposing vectors in a low-dimensional space, this analysis attempts to provide a graphical display of the $\mathrm{X}$ data matrix in a plot [37]. A set of objects was positioned and perceptually mapped using this analysis (rows from the $\mathrm{X}$ data matrix). The bi-plot analysis process necessitates data from a variety of objects with attributes (columns from the data matrix X) that are measured using interval and ratio scales. The analysis' final results are displayed in the form of a two-dimensional image display that includes information about (1) the object's relative position. Two objects with the closest distance are said to have a high level of similarity based on the observed attributes based on this information; and (2). the relationship between attributes. Based on this data, the linear relationship (correlation) between attributes and the level of importance of an attribute based on its variants can be determined. A bi-plot is a graph that combines information (1) and (2). The observed attributes were used to determine the characteristics of each object.

\section{Results and Discussion}

Because the soil is made up of boulders of various shapes and sizes, the behaviour of the subgrade is determined by the natural conditions in which the soil is formed [38]-[40]. This is demonstrated by the fact that the rock mineral content is nearly identical to that of the soil. Rocks of the Tuff type, such as Tuff Pasiran, are commonly found in West Lampung province [32]. Sandy tuff has a fresh grey to brownish grey colour, a medium to coarse texture, a round to very round grain shape, is well sorted, has good permeability, can be kneaded, and contains mica and pumice [33].

The main road to several areas in West Sumatra was used for the research. This route begins in the Bukit Kemuning area, which is administratively part of the North Lampung Regency. Given that the western route of Liwa - Bukit Kemuning is currently used as a feeder road, its function is critical. Every day, various types of large tonnage vehicles and even vehicles between provinces travel this route. Surprisingly, this path has the same rock diversity as the previous one, but part of the route is an earthquake path. It is a route that passes through a hilly topographic area with a steep slope to a very steep slope in the West Lampung area. The 
occurrence of landslides on the slopes along this route is common, resulting in access loss.

In Lampung Province, which faces a high risk of geo-disasters, the West Lampung area is one of the most vulnerable areas. This area is formed by young volcanic rocks that have not been properly consolidated in terms of geology [41]. The morphology consists of steep, wavy hills with deep valleys that are traversed by rivers with a very lowdensity level and are located between 500 and 1200 metres above sea level [32], [42]. It contains grains of rock ranging in size from fine to large. Because this location feels as though it has been exposed to altitude and is a part of the plain with an average elevation of $800-1,400$ metres above sea level, it experiences high rainfall.

From this intriguing case, a study was conducted in which a sample was taken in a disturbed manner and placed in a sack as research material. The soil's physical properties and unsoaked CBR values were determined in this study. The CBR value can serve as a reference point for planning road construction, parking lots, and other infrastructure projects. The soil density and CBR values were determined from the subgrade to the pavement's top layer [38], [40], [43]. If the CBR value is less than $6 \%$, the land cannot be used as a road body, or it can be used for trafficking purposes to increase the CBR value above $6 \%$. One of them is compaction or soil replacement.

The soil properties, compaction, and CBR values (see Table 1) obtained during the research were statistically plotted using the Bi-plot method. The Bi-plot method's output allows for easy mapping of the study area's soil type. According to laboratory analysis, the clay soils that comprise the study area are generally classified as heavy clay $(\mathrm{CH})$ and heavy silt $(\mathrm{MH})$ soil types, referring to the Unified Soil Classification System (USCS), with a high degree of plasticity; this classification is based on the AASHTO classification system [5], [39].
Table 1. CBR Values and Physical Properties
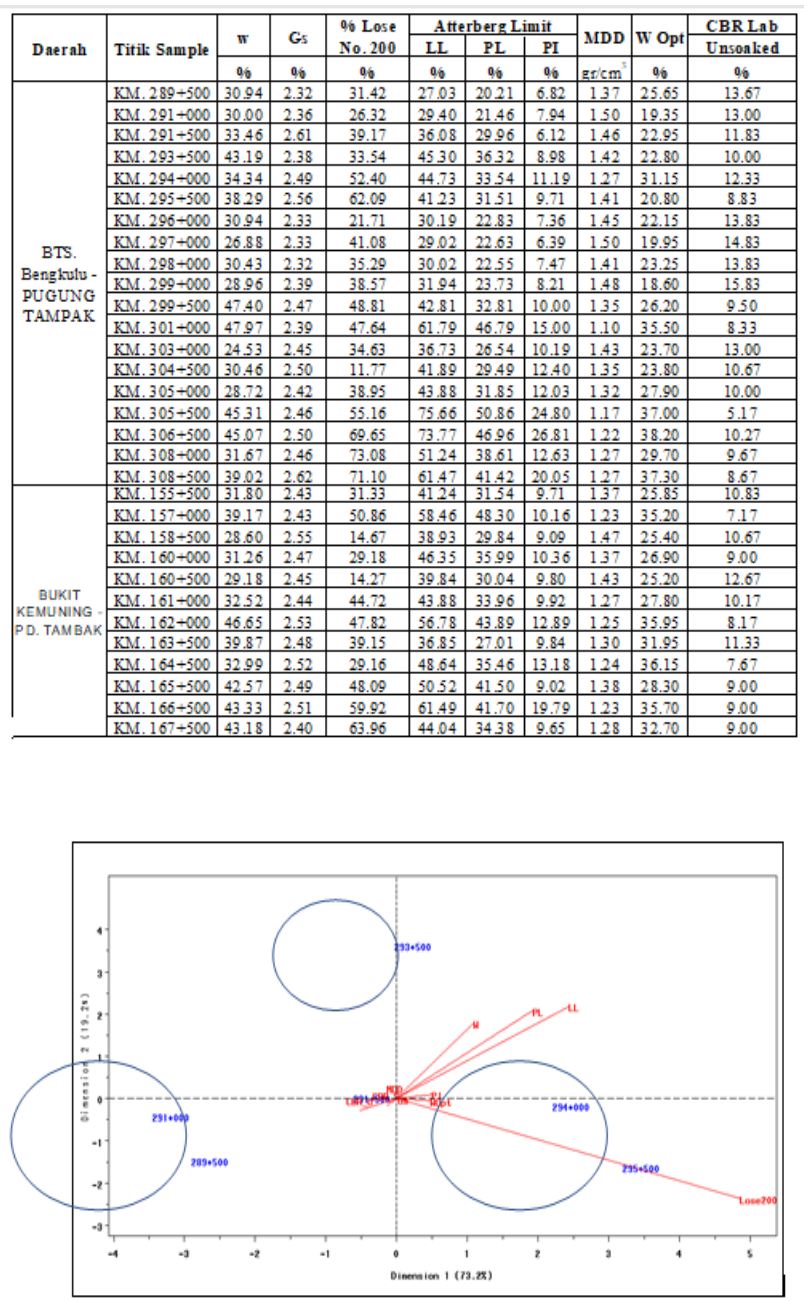

Fig. 3: Soil Sample Analysis at KM $293+500$

As illustrated in Figure 2, the KM $293+500$ soil sample has high values for the Atterberg Limits PL, LL, and Water Content (w). While soil samples from the KM $294+500$ and KM $295+500$ areas exhibit identical physical properties, according to the data, the percentage of data that passed the No. 200 indicates that the Percent Lose filter 200 has a high content. This indicates that the area's soil contains a high concentration of clay. Physical properties of the soil, such as the Water Content (W), correlate positively with the Atterberg Limits of Plastic Limit (PL), Liquid Limit (LL). This means that increasing the amount of water in a soil sample increases the value of soil plasticity, specifically the Plasticity Index (PI) and LL.

Additionally, as shown in Table 1, soil samples containing the Percent Lose filter value exhibit a positive correlation with the optimum water content value (W Opt), implying that the higher the Percent Lose filter value content in the soil sample, the higher the $\mathrm{W}$ Opt. The values of the Atterberg Limits PL, LL, W Opt, Water Content (W), and PI 
are inversely related to CBR. This means that as the $\mathrm{CBR}$ value in the soil sample increases or decreases, the moisture content of W Opt, the Atterberg Limits PL, LL, W Opt, W, and PI decreases.

The area surrounding the sampling location exhibits similar soil conditions based on the sampling location's five points. The formed line indicates that the soil conditions are at node $\mathrm{O}$. This indicates that the soil conditions in these locations are similar, implying that the soil parameters are uniformly similar. This minor variation is reflected in the circles created. Soil parameters are relatively uniform. It is simply that the difference in the condition of the per cent passed through the 200 sieves indicates that there are two locations with varying clay contents, namely those with high clay content. This is also illustrated in Table 1 and Figure 3.

The CBR value, on the other hand, remains high. This frequently occurs because the soil sampled has a high clay content but also contains sand and gravel. As a result, the CBR value is quite high. However, in this case, the CBR value is nearly uniform when compared to soil samples from other locations, despite the fact that the clay content of the soil varies.

The physical characteristics of the other area, which is 4 kilometres long with sampling at seven test locations, are discussed in Figure 4.

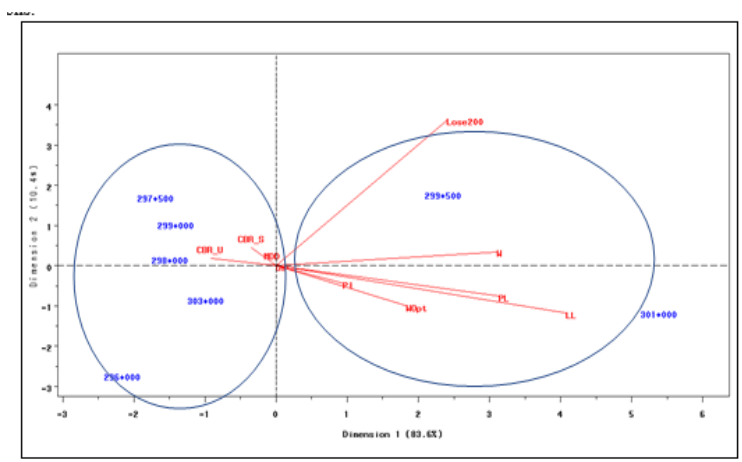

Fig. 4: Soil Sample Analyses at KM $297+500,299$ $+000,298+000,303+000,296+000, \mathrm{KM} 299+$ 500 and $301+000$

In Figure 4 above, soil samples are classified into two groups based on their physical properties and CBR values: group $1(\mathrm{KM} 297+500,299+$ $000,298+000,303+000$, and $296+000)$ and group $2(\mathrm{KM} 299+500$ and $301+000)$. Group 1 soil samples (circle on the left) contain a high CBR value, unlike Group 2 soil samples, which contain high Percent Lose filter values of 200, the Atterberg Limit PL, LL, PI, W, and W Opt.
As shown in Figure 3, the physical properties of the soil, specifically the water content, w, have a positive correlation with the Atterberg Limits PL, LL, W Opt, and PI. This means that as the water content of the soil sample increases, the Atterberg limit, PL, LL, W Opt, and PI values increase proportionately. Meanwhile, the CBR value is inversely proportional to W Opt, the Atterberg Limit PL, LL, W Opt, and W. This means that the CBR value increases as the $\mathrm{W}$ Opt, the Atterberg Limit PL, LL, W Opt, W, and PI values decrease.

The classification of soil data varies by region, or there may be an area with extremely dominant physical characteristics. This is illustrated in Figure 5.

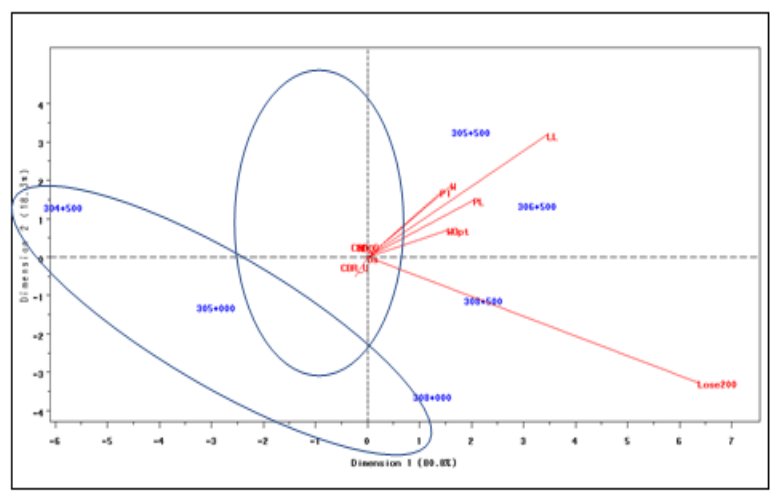

Fig. 5: Soil Sample Analysis of KM $306+500$ and $305+500$

As illustrated in Figure 5, the KM $306+500$ and $305+500$ soil samples contain high values for the Atterberg Limit PL, LL, per cent pass 200, and W Opt. Meanwhile, the water content, w, correlates positively with the Atterberg Limits PL, LL, PI, and W Opt. This means that the more water in the soil, the higher the concentrations of Atterberg Pl, LL, PI, and W Opt. CBR values are inversely proportional to W Opt, Atterberg Limit PL, LL, W Opt, and $\mathrm{W}$. This means that the higher the CBR value in a soil sample, the lower the concentrations of W Opt, the Atterberg Limit PL, LL, W Opt, W, and PI. As a result, it can be concluded that the moisture content of the soil has an effect on all soil parameters. Indeed, the water content of the soil is required, specifically as a lubricant. This frequently occurs during compaction work in the field. However, excessive water content results in a reduced capacity of the soil to bear weight [5], [40], [43]. The area around Bukit Kemuning - PD Tambak is depicted in Figure 6, specifically, from $\mathrm{KM} 155+500$ to KM $166+500$.

Figure 6 demonstrates that soil samples up to a distance of 6 kilometres are similar, and the CBR 
value is also quite good. However, due to the distance from Bukit Kemuning, the soil conditions are quite harsh, as indicated by the increasing CBR value and the increasing value of Maximum Dry Density. The maximum dry density value is determined through Proctor Standard, DAS, and other experiments designed to determine the density of soil. In this case, soil density becomes critical for changes in CBR values.

The soil conditions at KM $157+000$ are slightly different in that the soil contains a high proportion of clay, as evidenced by the higher percentage of clay that passes through filter No. 200 when compared to other soil locations. As a result, it will have an effect on the water content value, the optimum moisture content, and the Atterberg Limit. Among other physical properties, per cent loss No. 200 exhibits a great deal of variation. The Atterberg Limit experiment results, which yielded LL and PL values, revealed a positive or positive correlation between soil physical properties and the Optimum Moisture Content (OMC) (see Figure 5). This means that as the LL value in the soil sample increases, the PL and OMC values increase as well. However, the CBR value is inversely proportional to the LL, PL, and OMC values. This means that as the Atterberg Limit LL, PL, and OMC values decrease, the CBR value decreases as well. The percentage of material passing through sieve No. 200 is determined through sieve analysis experiments.

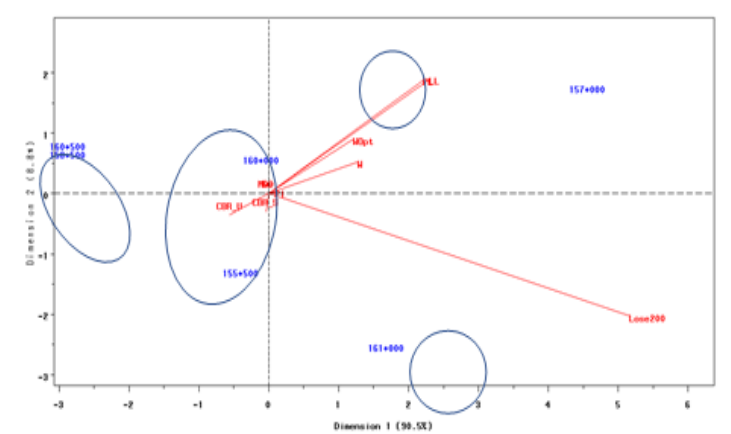

Fig. 6: Analysis of Soil Sample from KM $155+100$ to $160+000$

As illustrated in Figure 6, the soil samples at KM $155+100$ and $160+000$ have a high CBR value and a low density, Maximum Dry Density (MDD). In contrast, the soil samples at KM $157+$ 000 have a high water content, affecting the LL, PL parameters. Among other physical properties, per cent loss No. 200 exhibits a great deal of variation. The Atterberg Limit LL soil physical properties are positively correlated with PL, W, and W Opt. This means that as the water content increases, the LL,
$\mathrm{PL}$, and $\mathrm{W}$ Opt values increase as well. The CBR value is inversely proportional to the content of the Atterberg Limit LL, PL, W, and W Opt. This means that the greater the CBR value, the lower the LL, PL, W, and W Opt values will be.

The local soil conditions provide insight into the conditions that resulted in the formation of the rocks. This condition cannot be maintained indefinitely, as environmental factors such as earthquakes, heavy rainfall, chemical, biological, and other factors all affect the rock formation (Bell; Das), as illustrated in Figure 7 below.

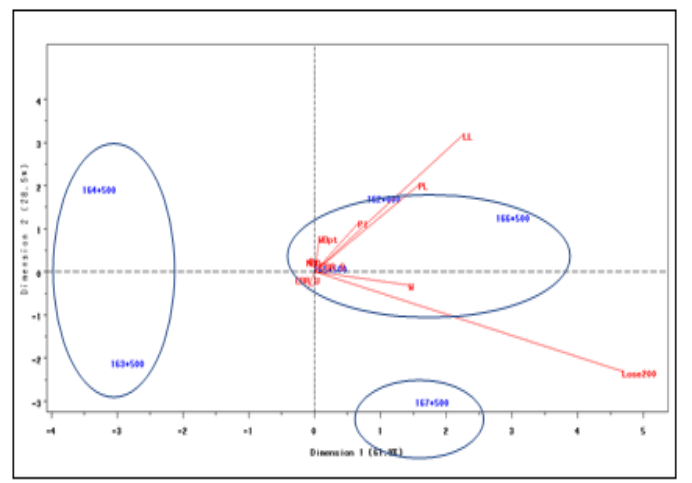

Fig. 7: Soil Sample Analysis from KM $162+000-$ $167+500$

As illustrated in Figure 7, the KM $162+000$ and $166+500$ soil samples contain the Atterberg Limit values, PL and LL. Meanwhile, the soil sample KM $167+500$ contains a high Percent Lose value. Physical properties of the soil, such as water content (WC), correlate positively with the percentage of particles passing through filter No. 200. The higher the water content in the soil sample, the greater the percentage of water content that passes through filter No. 200. This means that a soil sample with a high clay content will have higher PL and LL values.

As illustrated in Figures 7 and 8 , after experimenting with the Atterbeg Limit method and obtaining the LL and PL values, it is possible to determine the soil properties, conditions, and types. Civil engineers determine the soil type through a series of experiments on the soil's physical properties, including moisture content, density, the Atterberg Limit, and filter analysis. This series of experiments is to ensure that the condition and type of soil are accurately determined, as this parameter will be used in subsequent civil engineering work.

The novelty of this article is to provide information and scientific developments for civil engineering regarding how statistics, specifically the Bi-plot, can assist civil engineering scientists in 
determining soil type classifications, which can then be used to forecast the condition of soil density values. If the soil type and condition of the soil are known, the land can be used to construct roads, parking lots, and embankments, among other things. Because if the land does not meet geotechnical requirements, it cannot be used; however, if circumstances require the use of local soil, certain chemicals or other substances are added to it and mixed with the soil to increase soil stability.

Figure 6 depicts a condition that is distinct from that depicted in Figure 6 . The figure indicates that the soil sample contains the Atterberg Limit LL, PL, and $\mathrm{OMC}$ values that are positively correlated with the content of CBR values. This means that increasing the value of the Atterberg Limits LL, PL, and $\mathrm{W}$ Opt can result in an increase in the density of the soil and its CBR value.

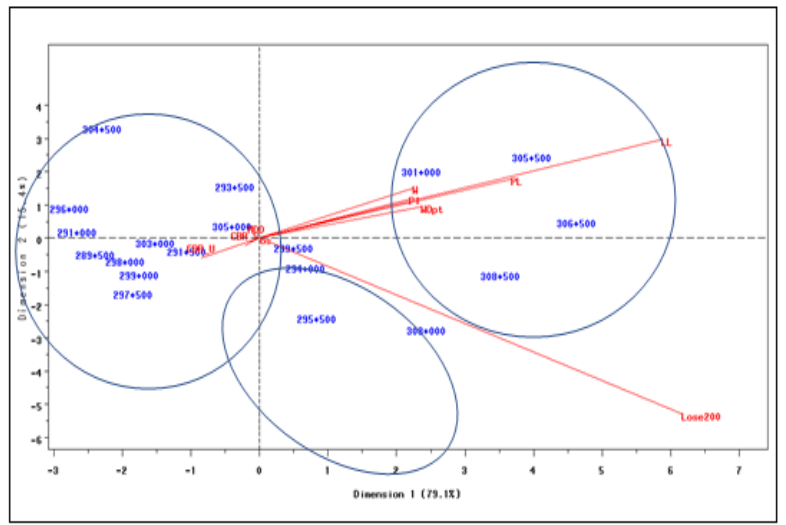

Fig. 8: Test Pit Data (Bengkulu - Pugung Tampak)

The overall map of soil sample characteristics in the Bengkulu - Pugung Tampak area is shown in Figure 8. Whereas, in general, soil samples are classified into three groups based on their physical characteristics and CBR value, with each group sharing some physical characteristics and CBR value similarities. Percent Lose filter 200 and the Atterberg Limit LL are two soil physical properties that have a high content value and diversity. The contents of $\mathrm{W}$ and $\mathrm{W}$ Opt have a very strong positive correlation with the contents of the Atterberg Limits LL, PL, and PI. This means that increasing the $\mathrm{W}$ and $\mathrm{W}$ Opt content in a soil sample increases the Atterberg Limit LL, PL, and PI contents, whereas the CBR value has a negative correlation with the Atterberg Limit LL, PL, PI, W, and $\mathrm{W}$ Opt contents. This means that as the CBR value in the soil sample increases, the Atterberg Limit values LL, PL, PI, W, and W Opt decrease. Because the MDD content of each soil sample is relatively low, it can be seen that the conditions around the centre value of 0 are relatively stable.

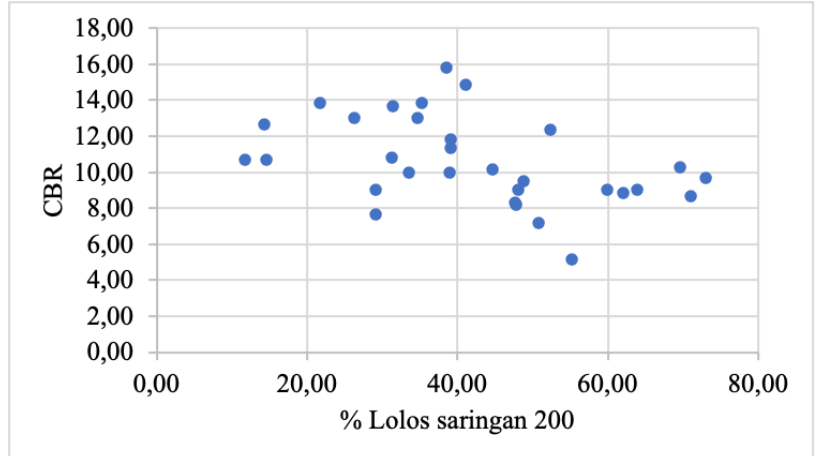

Fig. 9: Relationship between \% Pass through Filter and CBR

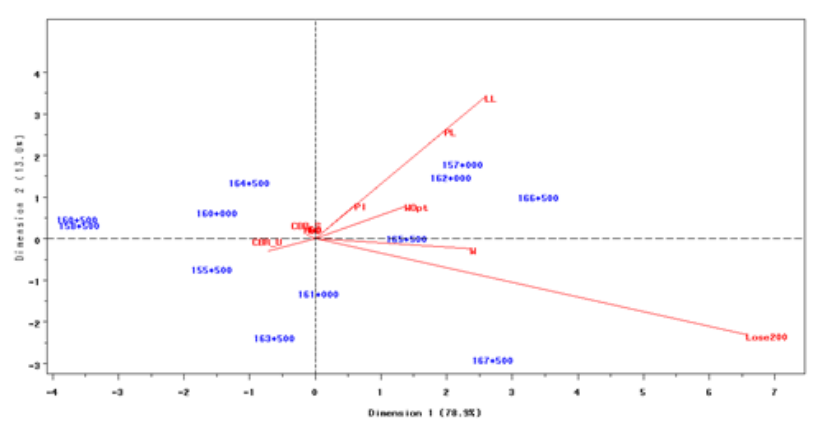

Fig. 10: Test Pit Bi-plot Data (Bukit Kemuning Pugung Tampak)

The overall mapping of soil sample characteristics in the Bukit Kemuning - Pugung Tampak area is shown in Figure 9. As illustrated in Figure 8 , soil samples are classified into three groups based on their physical properties and CBR value, with each group having some similarities in terms of physical properties and CBR value. Percent Lose Filter No. 200 describes the physical properties of soils with a high content value and a high degree of diversity (long line in Figure 10). The value of $\mathrm{W}$ and the W Opt contents are highly correlated with the Atterberg Limit LL, PL, and PI contents. This means that the greater the amount of $\mathrm{W}$ and $\mathrm{W} O \mathrm{Opt}$ in the soil sample, the greater the amount of the Atterberg Limit LL, PL, and PI. Meanwhile, the CBR value is inversely proportional to the content of the Atterberg Limit LL, PL, PI, W, and W Opt. This means that the greater the CBR value in a soil sample, the lower the Atterberg Limit values for LL, PL, PI, W, and W Opt. The MDD content of each soil sample is relatively low; it is shown to be close to the centre value of 0 , indicating that the MDD value has not varied significantly. 


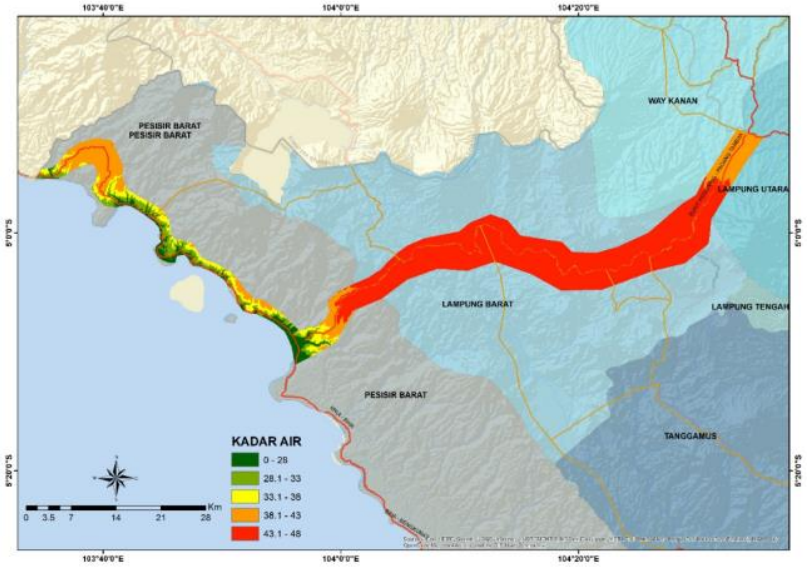

Fig. 11: Data Plotting of Water Content Values Distribution

\section{Conclusion}

It is extremely precise in the Bi-plot programme, which was used to determine the similarity of land locations. The similarities and differences revealed by the analysis serve as a guide for civil engineering in terms of determining the source point of soil material suitable for use as a landfill in civil engineering construction. The data used in the CBR test were the results of physical property testing and soil sample testing. This parameter was chosen using a sample of 31 samples spread over a distance of 31 kilometres. The test results indicate that a 31kilometre distance does not result in a significant difference in soil properties, which are generally similar except for areas with high clay content. Additionally, the laboratory analysis results indicate that the amount of water in the soil sample has an effect on the LL, PL, MDD, and CBR values. The less water in the soil, the lower the plastic limit value, and thus the lower the CBR value.

The findings of the current study also have implications. It is widely known that the government or contractors must use local land in order to find better land. Apart from being more cost-effective and quicker to obtain, it saves time at work. Therefore, the findings of this study are extremely useful in determining the location of existing land. In addition, they can be used to map conditions associated with specific soil types or differences within an area. Therefore, if the government, contractors, or consultants intend to utilise the land surrounding the study site, it is critical that this data be utilised because typically, before soil is used as a landfill, it is tested in a soil mechanics laboratory to determine its physical properties. If the requirements for roads and other earthworks do not comply with those of the
Directorate General of Highways (DGH), the land cannot be used as a landfill or for any other purpose.

\section{References:}

[1] J. A. Baldock and J. O. Skjemstad, "Role of the soil matrix and minerals in protecting natural organic materials against biological attack," Org. Geochem., vol. 31, no. 7-8, pp. 697-710, 2000.

[2] J. K. Mitchell, K. Soga, and others, Fundamentals of soil behavior, vol. 3. John Wiley $\backslash \&$ Sons New York, 2005.

[3] F. Bergaya and G. Lagaly, "General introduction: Clays, clay minerals, and clay science," Dev. clay Sci., vol. 1, pp. 1-18, 2006.

[4] Y. Zhu, Y. Li, N. Zheng, S. J. Chapman, and H. Yao, "Similar but not identical resuscitation trajectories of the soil microbial community based on either DNA or RNA after flooding," Agronomy, vol. 10, no. 4, p. 502, 2020.

[5] B. M. Das and K. Sobhan, Principles of geotechnical engineering, 9th ed. Boston: Chengage Learning, 2018.

[6] E. C. Brevik et al., "The interdisciplinary nature of SOIL," Soil, vol. 1, no. 1, pp. 117129, 2015.

[7] F. Liang, C. Wang, and X. Yu, "Widths, types, and configurations: Influences on scour behaviors of bridge foundations in non-cohesive soils," Mar. Georesources $\backslash \&$ Geotechnol., vol. 37, no. 5, pp. 578-588, 2019.

[8] Y. Guo, Y. Yang, and X. B. Yu, "Influence of particle shape on the erodibility of noncohesive soil: Insights from coupled CFD-DEM simulations," Particuology, vol. 39, pp. 12-24, 2018.

[9] S. Gul, J. K. Whalen, B. W. Thomas, V. Sachdeva, and H. Deng, "Physico-chemical properties and microbial responses in biochar-amended soils: Mechanisms and future directions," Agric. Ecosyst. Environ., vol. 206, pp. 46-59, Aug. 2015, doi: 10.1016/j.agee.2015.03.015.

[10] G. Baiamonte, G. Crescimanno, F. Parrino, and C. De Pasquale, "Effect of biochar on the physical and structural properties of a sandy soil," CATENA, vol. 175, pp. 294303, Apr. 2019, doi: 10.1016/j.catena.2018.12.019.

[11] M. Azeem et al., "Biochar improves soil quality and N2-fixation and reduces net 
ecosystem $\mathrm{CO} 2$ exchange in a dryland legume-cereal cropping system," Soil Tillage Res., vol. 186, pp. 172-182, Mar. 2019, doi: 10.1016/j.still.2018.10.007.

[12] Z. Jin et al., "Soil acidity, available phosphorus content, and optimal biochar and nitrogen fertilizer application rates: A fiveyear field trial in upland red soil, China," $F$. Crop. Res., vol. 232, pp. 77-87, Feb. 2019, doi: 10.1016/j.fcr.2018.12.013.

[13] R. R. Weil and N. C. Brady, The nature and properties of soils, 15th ed. New York: Pearson Education, 2017.

[14] F. J. Caniego, R. Espejo, M. A. Martín, and F. S. José, "Multifractal scaling of soil spatial variability," Ecol. Modell., vol. 182, no. 3-4, pp. 291-303, Mar. 2005, doi: 10.1016/j.ecolmodel.2004.04.014.

[15] F. . Caniego, M. . Martí, and F. San José, "Rényi dimensions of soil pore size distribution," Geoderma, vol. 112, no. 3-4, pp. 205-216, Mar. 2003, doi: 10.1016/S0016-7061(02)00307-5.

[16] A. Biswas, H. P. Cresswell, H. W. Chau, R. A. Viscarra Rossel, and B. C. Si, "Separating scale-specific soil spatial variability: A comparison of multi-resolution analysis and empirical mode decomposition," Geoderma, vol. 209-210, pp. 57-64, Nov. 2013, doi: 10.1016/j.geoderma.2013.06.003.

[17] S. Dongli et al., "Multi-scale correlations between soil hydraulic properties and associated factors along a Brazilian watershed transect," Geoderma, vol. 286, pp. 15-24, Jan. 2017, doi: 10.1016/j.geoderma.2016.10.017.

[18] X.-H. Long et al., "Applying geostatistics to determine the soil quality improvement by Jerusalem artichoke in coastal saline zone," Ecol. Eng., vol. 70, pp. 319-326, Sep. 2014, doi: 10.1016/j.ecoleng.2014.06.024.

[19] M. A. Oliver, "Geostatistics and its application to soil science," Soil Use Manag., vol. 3, no. 1, pp. 8-20, Mar. 1987, doi: 10.1111/j.1475-2743.1987.tb00703.x.

[20] B. G. Look, "Soil classification and description," in Handbook of Geotechnical Investigation and Design Tables, London, UK: CRC Press, 2017, pp. 43-56.

[21] A. Dione, M. Fall, Y. Berthaud, F. Benboudjama, and A. Michou, "Implementation of resilient modulus--CBR relationship in mechanistic pavement design," Sci. Appliquées l'Ingénieur, vol. 1, no. 2 , pp. 65-71, 2014.
[22] D. K. Choudhary and Y. P. Joshi, "A detailed study of Cbr method for flexible pavement design," Int. J. Eng. Res. Appl., vol. 4, no. 6, pp. 239-253, 2014.

[23] N. Alamanis, P. Lokkas, T. Chrysanidis, D. Christodoulou, and E. Paschalis, "Assessment Principles for the Mechanical Behavior of Clay Soils," WSEAS Trans. Appl. Theor. Mech., vol. 16, pp. 47-61, Aug. 2021, doi: 10.37394/232011.2021.16.6.

[24] R. F. Craig, Soil Mechanics. Jakarta: Erlangga, 1991.

[25] S. Hussain, "Effect of Compaction Energy on Engineering Properties of Expansive Soil," Civ. Eng. J., vol. 3, no. 8, p. 610, Sep. 2017, doi: 10.28991/cej-030988.

[26] N. I. Abd Karim, S. A. Kamaruddin, and R. Che Hasan, "Modeling of Petrophysical Relationship of Soil Water Content Estimation at Peat lands," Int. J. Integr. Eng., vol. 10 , no. 7, pp. $177-187$, Nov. 2018, doi: 10.30880/ijie.2018.10.07.017.

[27] A. Bharath, M. Manjunatha, T. V Reshma, S. Preethi, and others, "Influence and correlation of maximum dry density on soaked \& unsoaked CBR of soil," Mater. Today Proc., 2021.

[28] S. M. Lakshmi, S. Subramanian, M. P. Lalithambikhai, A. M. Vela, and M. Ashni, "Evaluation of soaked and unsoaked CBR values of soil based on the compaction characteristics," Malaysian J. Civ. Eng., vol. 28, no. 2, 2016.

[29] D. S. Subardja, S. Ritung, M. Anda, S. E. Sukarman., and R. . Subandiono, "National Soil Classification Technical Guidelines," Bogor, 2016.

[30] Z. Ahmad, W. M. San, A. Damayanti, R. M. Baharudin, and Z. Daud, "Study on the Natural Soil Properties Endau Rompin National Park (PETA) as Compacted Soil Liner for Sanitary Landfill," Int. J. Integr. Eng., vol. 5, no. 1, pp. 14-16, 2013.

[31] J. E. Bowles, Engineering Properties of Soils and Their Measurement, 4th ed. New York: McGraw-Hill, 1992.

[32] P. Iqbal and A. Mulyono, "Geologi Teknik Tanah Penyusun Lereng Lintas Barat Km 030, Liwa, Lampung Barat Kaitannya dengan Potensi Longsor," in Prosiding Pemaparan Geoteknologi, 2014, pp. 143-149, doi: http://dx.doi.org/10.33332/jgsm.geologi.v19i 3.387.

[33] P. Iqbal, "Pemanfaatan Tuf Pasiran untuk Bahan Bangunan di Daerah Liwa, Lampung 
Barat," Maj. Pusdiklat Geol., vol. IX, pp. 51-58, 2013.

[34] A. Sujeeth, "CBR test equipment," 2015. https://www.researchgate.net/publication/342 510129_AN_INVESTIGATION_INTO_TH E_GEOTECHNICAL_ENGINEERING_PR OPERTIES OF LATERITE SOILS IN NI LAI_MALĀYSIA_Ahmed_Sujeeth_BEng Hons_in_Civil_Engineering/figures? ${ }^{-} \mathrm{l}=1$ (accessed Oct. 02, 2021).

[35] C. Pandey and S. Agarwal, "Comparative study betwen soaked and unsoaked value of soil samples," Int. Res. J. Eng. Technol., vol. 6, no. 6, pp. 3259-3264, 2019.

[36] D. Joseph and C. Vipulanandan, "Characterization of field compacted soils (unsoaked) using the California Bearing Ratio (CBR) test," in Geo-Frontiers 2011, Mar. 2011, pp. 2719-2728, doi: $10.1061 / 41165(397) 278$.

[37] I. Jolliffe, "Principal component analysis," in Encyclopedia of Statistics in Behavioral Science, Chichester, UK: John Wiley \& Sons, Ltd, 2005.

[38] L. Afriani, I. Adha, and Setyanto, "Innovative design of soil pressure modeling test apparatus to determine the amount of soil compaction energy to dry density value," IOP Conf. Ser. Earth Environ. Sci., vol. 245, p. 012039, Mar. 2019, doi: 10.1088/17551315/245/1/012039.

[39] H. C. Hardiyatmo, Mekanika Tanah I (Soil Mechanics I), 4th ed. Yogyakarta: Gadjah Mada University Press, 2006.

[40] F. G. Bell, "Lime stabilization of clay minerals and soils," Eng. Geol., vol. 42, no. 4, pp. 223-237, Jul. 1996, doi: 10.1016/0013-7952(96)00028-2.

[41] T. C. Amin, Kastowo, and G. W. Leo, Peta geologi lembar Padang, Sumatera (Geological map of the Padang quadrangle). Bandung: Pusat Penelitian dan Pengembangan Geologi, 1996.

[42] E. Soebowo, S. Kusumadharma, A. S, Djakamihardja, and S. Wibawa, "Geologi longsoran pada jalur Liwa-Krui, Lampung Barat (Geology of landslides on the LiwaKrui route, West Lampung)," 1997.

[43] F. G. Bell, Engineering Treatment of Soil, 1st ed. London: E \& FN Spon, 1993.

\section{Contribution of Individual Authors to the Creation of a Scientific Article (Ghostwriting Policy)}

Lusmeilia Afriani drafted the manuscript, collected data, and conducted the analysis. Nusyirwan and Ryzal Perdana conducted the literature review, drafted the general conclusions, edited the language, and were responsible for the paper's formatting and revision. Rina Febrina and Yan Juansyah enhanced the study's structure, clarified the analysis, completed the paper's finalisation, and developed the abstract.

\section{Sources of Funding for Research Presented in a Scientific Article or Scientific Article Itself}

We would like to express our gratitude to the Faculty of Engineering of the University of Lampung for facilitating and assisting with the field survey and data collection, as well as providing financial support.

\section{Creative Commons Attribution License 4.0}

\section{(Attribution 4.0 International, CC BY 4.0)}

This article is published under the terms of the Creative Commons Attribution License 4.0 https://creativecommons.org/licenses/by/4.0/deed.en US 